\title{
Las heridas de la memoria: Héctor Abad Faciolince*
}

\author{
Teresa García Díaz ${ }^{1}$ \\ Universidad Veracruzana (México)
}

\section{Resumen}

El artículo analiza la relación que el escritor colombiano Héctor Abad Faciolince, mediante las novelas El olvido que seremos, Traiciones de la memoria y el poemario Testamento involuntario, establece entre los procesos de olvido y recuperación de la memoria personal y colectiva.

\section{Abstract}

This article explore the relation between the process of forgetting and the recovery of the personal and collective memory found in the work of the Colombian writer Héctor Abad Faciolince in the novels El olvido que seremos, Traiciones de la memoria, and the poems collection Testamento involuntario.

Keywords: Colombian literature, memory, paternity, forgetting.

lombiana, memoria, olvido, paternidad.

"El mundo en que morimos se opone al mundo en que vivimos como lo inaccesible a lo accesible."

Georges Bataille.

Caminar por los textos. Qué mejor manera para el escritor colombiano Héctor Abad Faciolince de desafiar el olvido que reconstruir fragmentariamente la vida del padre en varias de sus obras. El

\footnotetext{
* "The injuries of memory: Héctor Abad Faciolince".

Recibido: 15 de octubre de 2013 - Aprobado: 20 de noviembre de 2013.

${ }^{1}$ Doctora en Literatura Mexicana de la Universidad Nacional Autónoma de México, con residencia posdoctoral en la Universidad de Bologna y El Colegio de México. Miembro del Sistema Nacional de Investigadores Nivel 1. e-mail: teresagarciadiaz@ yahoo.com
} 
subterfugio de que en su pluma el personaje de su progenitor camine por diferentes géneros, poesía, novela, crónica, logra revitalizar una gran figura pública desaparecida, al compartirla con todos los lectores de diferentes latitudes y geografías. Su obra más conocida es la novela El olvido que seremos, donde el duelo por la pérdida del padre a manos de un sicario motiva al autor a recuperar su historia familiar, que abarca tres generaciones, desde su niñez hasta el asesinato del padre, cuando Faciolince tiene veintiocho años de edad.

En el poema "Memento", ${ }^{2}$ incluido en Testamento involuntario, el escritor describe su percepción infantil de la figura paterna, y hace explícitos sus sentimientos hacia ella: "Mi padre era doctor y olía a limpio./ Me gustaba el recuerdo de su olor/ sobre la almohada/ cuando se iba de viaje,/ y miraba hechizado/ cuando estaba en la casa/ su brocha de afeitar" (116). Como puede advertirse, la presencia y la ausencia del padre son sumamente trascendentes en la infancia de Faciolince. Tanto en la novela como en el poema, se expresa un mayor afecto hacia el padre que por cualquier otro integrante de la familia. Este afecto se hace explícito en la atención a los pequeños detalles que anunciaban su presencia en los espacios cotidianos: "Por la mañana amaba/ las huellas de sus pies en las baldosas/ y los rollitos de los calcetines/ dejados en el suelo" (116). La ternura evocada en estos versos puede conmover al lector, al imaginar a ese niño que adora al padre y que sobrevive en la autoficción de Héctor Abad Faciolince.

El escritor creció con seis madres: las cinco hermanas y la madre, que hablaban demasiado. Cabe subrayar que en ese contexto familiar, como en toda familia, existían secretos ${ }^{3}$. Aunque los hombres de la casa hablaban menos, en la novela se recuperan trascendentes conversaciones que manifiestan el profundo lazo y la transparencia con que asumían diversos temas vitales. Las conversaciones mantenidas posibilitaron delinear un mapa vital que ayudaría a Abad Faciolince a caminar firmemente por la vida ${ }^{4}$. Ese universo femenino de alguna manera pudo influir para reforzar la unión entre padre e hijo. Abad Faciolince enuncia que será escritor antes de serlo

${ }^{2}$ El poema está firmado: “Caracas, febrero de 1999”, mientras que la primera edición de la novela data de 2006.

3 Este contraste entre el desbordamiento lingüístico femenino y la actitud callada del autor, a la que alude la autoficción de Abad, se refleja en su escritura en una serie de situaciones que quedan ocultas o abiertas en el texto, y a las que no atenderé en este artículo.

${ }^{4}$ Se lee en la novela: "entre dos pasiones religiosas insensatas, una masculina, en el colegio, y otra femenina, en la casa, yo tenía un asilo nocturno e ilustrado: mi papá" (129). 
y el padre lo acredita como tal. A ese amor paterno se le suma el profundo respeto y admiración por su entereza y valentía, según los versos siguientes: "También era valiente y no envalentonado, / era manso y valiente/ porque estaba en peligro y no sentía miedo/ y su única arma eran las teclas/de una Olivetti azul/ o el azul de la tinta de un bolígrafo./ Eso ha tenido un nombre: resistencia" (118). A pesar de graves amenazas, su valerosa voz no dejó de hacerse oír a través de sus artículos, como se narra detalladamente en la novela. Nunca se amedrentó, y asumió una postura consecuente en su discurso, hasta llegar a las últimas consecuencias, con plena conciencia de que arriesgaba su vida. No apagó su voz ni perdió su serenidad: murió resistiendo. Confió hasta el último minuto en la gente que se le acercaba, y con total mansedumbre siguió las instrucciones de la mujer que lo guió al matadero 5 .

El yo poético logra describir en muy pocos versos toda una vida de intenso trabajo y de fuerte compromiso social, acorde con su clara postura política. El doctor Abad era un hombre que se daba a los otros y mantenía la coherencia en todos los ámbitos de su vida: "Como era liberal/ se decía cristiano y comunista/ porque amaba a los pobres,/ porque sufría con el sufrimiento" (2001: "Memento", 117-118). A pesar de haber tenido serias diferencias con la institución religiosa, murió con fe. Y el sufrimiento de los otros, aunque en apariencia le fuesen ajenos, lo conmovía al grado de arriesgar su propia integridad. Serán sus artículos el detonante principal para motivar la planeación de su asesinato, conjuntamente con los de otros personajes, como escribe Abad Faciolince. Una vez que su nombre ingresó en las listas de víctimas a ejecutar, su destino estaba marcado, pasaría a engrosar las cada vez más nutridas sumas de asesinados. Los sicarios contratados fueron eliminando a quienes estaban anotados y no alcanzaron a salir del país. Tachaban o borraban sus nombres ${ }^{6}$ :

Había en los bolsillos un poema

de Borges, "Epitafio",

una lista de muerte con su nombre,

5 En torno a la fenomenología de la percepción y su relación con el tiempo, en referencia a Husserl, Ricoeur (2000) considera que: "El obrar, en particular, posee sus nodos y sus vientres, sus rupturas y sus impulsos; el actuar es musculoso" (54). Por ello, considero que a los movimientos musculares, o a los impulsos que siguió el doctor Abad en la trama, deben sumarse los no dicho. Hay una serie de espacios vacíos en la novela que el lector llenará con su imaginario, y entonces se conmoverá o permanecerá ajeno al dramatismo de su muerte.

${ }^{6}$ En la lista referida, el nombre del doctor Abad estaba acompañado por el del periodista Jorge Child, el del excanciller Alfredo Vázquez Carrizosa, el del columnista Alberto Aguirre, entre muchos otros (355). 


\author{
y una bala incrustada \\ en el forro del cuello. \\ La bala fue una de las seis que lo mataron \\ y no la conservamos; \\ los nombres de la lista \\ fueron siendo borrados. \\ en los meses siguientes, \\ por los asesinos. \\ El poema decía: "Ya somos el olvido que seremos". \\ $\mathrm{Y}$ es verdad. A veces lo olvidamos. \\ Yo voy a recordarlo el día que me muera (119).
}

El poema del bolsillo le da un tinte poético a una situación tan devastadora e injusta. Puede decirse que en el momento de su muerte tenía en la bolsa del pantalón su propio epitafio: los versos de Borges. La brutalidad del asesinato contrasta con la sensibilidad de un hombre que llevaba consigo los versos que lo conmovían. En esa trascendencia de la palabra sobre la vida presente tanto en el poema como en la novela, y en todos los textos donde aparece el doctor, se confirma el carácter permanente de la palabra, pues ésta pervive mientras tenga lectores.

Los cuestionamientos sobre el hecho de que el doctor Abad le atribuyera esos versos a Borges motivaron la escritura de Traiciones de la memoria, texto donde se recupera la investigación realizada por Abad Faciolince para confirmar la autoría del poema, considerando versiones opuestas, mentiras, ficciones, intentos de plagio, "confabulaciones de la memoria" (45), acompañado todo esto por una serie de documentos que sustentan sus afirmaciones, hasta lograr llegar a la versión original: "me puse terco: quería luchar contra la negación de ese poema, de esos poemas" (61). En ese proceso comprueba que "así es la memoria: lo que uno recuerda, otro lo olvida, lo que es importante para uno, para otro carece de importancia y lo borra para siempre, llegándolo a negar aunque le haya ocurrido" (66). Y, asimismo, relata la forma de vida de la autoficción de Héctor Abad Faciolince en el interior de ese texto híbrido, dividido en tres relatos, que ronda el ensayo, el cuento y la autobiografía ${ }^{7}$.

\footnotetext{
${ }^{7}$ En el relato rastrea que el poema había sido publicado en Mendoza (Argentina), el 13 de septiembre de 1986, en Ediciones Anónimos, con el crédito a Borges; en el periódico La Jornada, en México, el 3 de mayo de 1987; y en El Espectador, el 29 de noviembre, también de 1987. La "publicación inicial fue de Tenorio en la revista Número (octubre de 1993)" Cf. Abad Faciolince (2009), para recuperar todas las ediciones que acreditaron, en diferentes tiempos y lugares, la autoría del poema de Borges que el doctor Abad llevaba en el bolsillo en el momento de su asesinato.
} 
"Cada partida es un adiós, aunque a veces impronunciado."

Antonio Prete

El abrazo fraterno. Héctor Abad integra a diferentes miembros de su familia en sus escritos. Pareciera buscar un equilibrio en los comentarios elogiosos, aunque en algunos momentos ello implique minimizar su propio perfil. Por ejemplo: el poema "Manicomio", del poemario homónimo, describe la relación fraternal que Héctor hijo mantiene con la madre y las hermanas, dando mínimo espacio a la presencia del padre: "Mi hermana la mayor arregla muertos./ Mi papá le enseñó y ella lo hizo" (2011c: 109); "la hermosa finca/ que nos dejó de herencia mi padre" (11). Una recepción inicial de esas líneas permite interpretar que dicho ejercicio poético es un intento de equilibrar la presencia de otros familiares en su escritura.

En el texto recorre las virtudes de cada uno de los integrantes de la familia, y resalta que la sexta hija es una buena médica: "Vive indignada/ con la pobreza de los otros/ y obsesionada con el sufrimiento" ("Manicomio", 110), y también apunta a que tenía problemas de dinero: "nunca paga las cuentas de la finca/ porque según parece no le alcanza la plata". Con esos rasgos, sus límites y sus virtudes, pareciera la más cercana al padre. El yo poético se minimiza frente a las habilidades de las hermanas: "me paso el día jugando con palabras" (112). Le resta valor a su trabajo creativo frente a los dones para la vida diaria y la calidad humana que distingue a las Abad Faciolince.

El narrador colombiano también describe los últimos días de la madre y su muerte en el cuento "Álbum", de El amanecer de un marido: "A veces creo que el infierno, si existiera, consistiría en poder ver, en el preciso instante de nuestra muerte, lo que están haciendo en ese mismo momento las personas a quienes hemos querido" (12). De acuerdo a la referencia, el sólo imaginar que quien amamos esté disfrutando o sufriendo, sin que el yo muerto sea mas que un testigo invisible, incapaz de hacerse presente en la vida del otro, en caso de ser "posible", debe ser dolorosísimo y convertirse en una verdadera vivencia infernal.

Esa exclusión de la vida de los seres queridos pareciera aproximarse mucho a cierto infierno personal. El imaginario de Abad Faciolince 
construye esa imagen con fragmentos de culpa, pues relata que olvidó la reunión semanal con la madre, y mientras él disfrutaba un encuentro con una mujer, la madre moría sola y con la sensación de abandono, derivada de su ausencia a la única comida disfrutable dentro de la rutina del asilo en que vivía. Al evocar, el personaje siente dolor: "La evocación no se siente (pathos) simplemente, sino que se sufre" (59). Culpa y sufrimiento colorean el recuerdo de la madre.

Es palmario el afecto por el padre que la autoficción de Héctor Abad construye, al igual que en el poema "Memento", pues sobrepasa y se desborda, yendo muy por encima de todos los sólidos sentimientos amorosos que tiene por los demás integrantes de su familia. ${ }^{8}$ Esa constante debe destacarse, porque necesariamente trasciende su pluma en los varios y distintos textos en que el autor implícito, o los relatos autoficticios de Faciolince, abren un espacio considerable para insertar la figura del padre. Para entender quién se es, es necesario saber de dónde se viene, y cómo se conforma como sujeto.

En El olvido que seremos, el lector conocerá un padre amorosísimo, envidia de todos los niños amigos del narrador, quienes desconocían el abrazo o el beso paterno. El machismo desviaba el afecto de sus padres, y esa carencia se manifestaba con burlas hacia él. El padre resulta ser un hombre colombiano tan auténtico que ante las dudas de su pequeño hijo, asustado y preocupado por sus propias reacciones físicas al contemplar los cuerpos desnudos y los juegos sexuales de sus compañeros, le responde que espere a estar seguro de sus preferencias, pero que de ser homosexual lo tome con tranquilidad, pues es una elección natural. Si el padre comparte su preocupación, evidente en la tristeza y el dolor de la voz, es sólo porque sabe que tendría una vida difícil en un contexto machista, no obstante, le aconseja que cuando tenga la certeza debe asumir su esencia, porque "lo peor en la vida es no ser lo que uno es [...] lo más devastador para la personalidad, eran la simulación o el disimulo, esos males simétricos que consisten en aparentar lo que no se es, recetas ambas seguras para la infelicidad y también para el mal gusto" (218).

Su padre fue un médico que no ejerció como tal, sino que se dedicó a nobles tareas como la docencia, a la prevención sanitaria en los barrios más pobres y fungió como el principal organizador de marchas y mítines, como forma de protesta, y en su discurso final en esos eventos, frecuentemente era detenido por la policía, aunque "le devolvían de inmediato la libertad, como avergonzados ante su

${ }^{8}$ Sólo hago referencia como lectora a la presencia literaria que conozco. 
evidente inocencia y dignidad" (325). De igual manera, se enriquece la figura del doctor al leer, también en el poema "Memento", otra construcción de la misma identidad de manera concisa por las características del verso:
Mi padre vacunaba por las selvas, daba horas y horas y más horas de clase en la universidad y también en las cárceles, participaba en marchas de protesta empuñando con furia sus pañuelos blancos y publicaba artículos en los periódicos diciendo el nombre de los torturadores, "capitán tal, sargento hijo de tal", denunciando secuestros, asesinatos y desapariciones (117-118).

Son esas últimas líneas del poema citadas las que aluden a otra expresión de su valiente lucha por los derechos humanos, realizada a través de artículos periodísticos en El Mundo de Medellín y en El Tiempo de Bogotá. Entre esos escritos destaca un texto sumamente arriesgado y duro en el que manifiesta una denuncia explícita, cuando un alumno y amigo suyo fue detenido y torturado sádicamente por el ejército de Medellín. En contraste con toda la maldad del entorno, el padre era un hombre que tenía la madurez suficiente para que, cuando lo rebasaba el enojo o el dolor proveniente de las injusticias, al llegar a casa con ese gris estado de ánimo, de inmediato y antes de hablar con nadie, se refugiara en su estudio a leer, a disfrutar libros de arte y a escuchar a Beethoven o a Bach, para sanar su pena y su rabia, y de ese modo salir limpio de cargas oscuras al encuentro con sus hijos y su esposa.

Aunque el doctor ya estaba anotado en las fatídicas listas, y había recibido infinidad de ataques y amenazas, se mantuvo firme en su postura y no abandonó su ciudad. Sus protestas aparentemente "no eran contestadas más que con un silencio hostil. Y la hostilidad fue creciendo de año en año hasta el desenlace final" (330). Era tan evidente el rechazo de mucha gente ante su labor y compromiso social, que una de sus hijas, quien se movía en las altas esferas, donde abundaban personajes cuyo horizonte era bastante limitado, ${ }^{9}$

\footnotetext{
${ }^{9} \mathrm{Al}$ describir el contexto en que vivía su hermana, escribe lo siguiente: "su mundito se reducía a ese vecindario que domina la ciudad desde las colinas: verde y sin aceras, plagado de edificios altos y bajos, de casas asediadas por los constructores, de carros blindados, de piscinas privadas, parques particulares, gimnasios, campos de golf y canchas de tenis, de centros comerciales mal copiados de Miami, tan irreales y postizos como un Disney World trasplantado a un valle andino de los trópicos." (18).
} 
solía decirle, bastante preocupada, que nadie lo quería porque nadie lo entendía. Ante ello el doctor respondía: "a mí sí me quiere mucha gente, pero no están por donde tú te mueves, están en otra parte, y algún día te voy a llevar a que los conozcas [...] El día del desfile que acompañó el entierro de mi papá por el centro, con miles de personas que agitaban pañuelos blancos en la marcha, y desde las ventanas, y en el cementerio, comprendió que en ese momento mi papá la estaba llevando a conocer a quienes sí lo querían" (331).

La figura del doctor Abad provocó sentimientos encontrados y sumamente contrastantes. Hubo quienes deseaban y consiguieron verlo muerto, y hubo quienes lo respetaban y amaban. Algunos de los miembros de la Iglesia, cuyos intereses estaban en pugna, lo despreciaban, a pesar de que su esposa era sobrina del arzobispo de Medellín, ${ }^{10}$ a quien en su vejez, aprovechando uno de sus lapsus de pérdida de memoria, lo hicieron firmar una carta en contra del doctor. Cuando se enteró por la sobrina, quien lo había escuchado en La hora católica, de lo que le habían hecho firmar, fue tanta su indignación que renunció a la arquidiócesis y se retiró a la casa de la abuela. El presbítero Fernando Gómez Mejía "lo odiaba con toda el alma, con una fidelidad y una constancia en el odio, que ya se las quisiera para el amor" (2011a: 73).

Otras figuras religiosas, en cambio, al igual que el doctor, tenían un fuerte compromiso social con quienes el doctor se entendía, como René García y Luis Alejandro, dos primos de la madre, "curas rebeldes", que se habían comprometido con la Teología de la Liberación, y a quienes en alguna ocasión debieron llevarles cobijas a la cárcel donde fueron recluidos por su labor. Irónicamente, en esa misma generación, dentro de la familia materna Joaquín García Ordoñez era el párroco más reaccionario de toda Colombia.

Los lazos de la madre con la Iglesia fueron trascendentes en la infancia de Héctor Abad Faciolince, pues la "hermanita" Josefa, una "monja de compañía" que le había sido asignada para fungir como su nana, le llenaba la cabeza de creencias religiosas y de relatos de santos sacrificados, en contraste con la educación del padre: "Entre dos pasiones religiosas insensatas, una masculina, en el colegio, y

Y con ello da espacio a un sector social frecuente en los países latinoamericanos, familias pudientes económicamente, para quienes el consumismo y el modelo estadunidense de vida, detonan los comportamientos que deben asumir en su vida diaria.

${ }^{10}$ Como se ha venido comentando, el lazo entre la familia materna y la iglesia era sólido, antiguo e importante: "en la familia de mi mamá lo que les venía por sangre eran las vocaciones sacerdotales" (107). 
otra femenina, en la casa, yo tenía un asilo nocturno e ilustrado: mi papá" (129), lo cual refuerza ese lazo tan fuerte con la figura paterna, pues ésta se convierte en un refugio, en un asidero que le permitía a ese niño liberarse de todas la perturbaciones, dudas y confusiones que derivaban de esas fuerzas. ${ }^{11}$ La novela contiene mucho dolor y desolación, pero también se desborda por todas sus páginas una inmensa alegría y mucha felicidad: se evidencia lo pleno y lo formativo que puede ser el amor paternal.

[...] gracias a la benéfica influencia de mi papá, he podido ser un malo que no ejerce, un cobarde que se sobrepone con esfuerzo a su cobardía y un avaro que domina su avaricia. $\mathrm{Y}$ lo que es más importante, si hay algo de felicidad en mi vida, si tengo alguna madurez, si casi siempre me comporto de una manera decente y más o menos normal, si no soy un antisocial $\mathrm{y}$ he soportado atentados y penas y todavía sigo siendo pacífico creo que fue simplemente porque mi papá me quiso tal como era [...] y me mostró el camino para sacar de esa mala índole humana que quizá todos compartimos, la mejor parte (152-153).

[...] Además, de mi papá aprendí algo que los asesinos no saben hacer: a poner en palabras la verdad, para que ésta dure más que la mentira (397).

El afecto incondicional a su padre, ese ser humano tan entrañable, se simboliza en el apego a la figura paterna que, desde la infancia, suele proporcionar equilibrio y seguridad, en ese abrazo que en las despedidas puede perderse y convertirse en una carencia, sea esta temporal o definitiva cuando no está o ya no estará el otro que representa un referente familiar original. El abrazo remite a lo primigenio, a la figura de un niño resguardado por un adulto, quien lo protege ante todo. Y por ello, la pérdida de ese equilibrio universaliza la experiencia de la pérdida. El olvido que seremos es el último abrazo que Héctor Abad Faciolince no pudo darle a su padre para despedirse, y que necesitaba para disolver el vacío de su ausencia. En ese sentido, recurrir a Prete (2010), en el Tratado de la lejanía, resulta muy pertinente:

\footnotetext{
${ }^{11}$ Otro de sus recuerdos infantiles relacionado con la Iglesia era que un ginecólogo había hecho un gran negocio: les había extirpado el útero a todas las novicias de Medellín para que no tuvieran miomas. Aunque su padre con mucho humor recitaba unas coplas de Nito Restrepo: "Una monja se embuchó/ de tomar agua bendita/ y el embuche que tenía/ era una monja chiquita" (84). En medio de ese combate existente en la institución religiosa, en el interior de la Iglesia había posiciones antagónicas y una intensa lucha en la guerra que se iniciaba.
} 
El abrazo es el umbral de la partida: un desafío al tiempo de la separación. Representación -alusiva, utópica- de la proximidad perpetua, del encuentro entre los cuerpos que anula el espacio, y el vacío, de la distancia. Anulando el espacio, se anula el tiempo de la lejanía. Cuanto más nos apretamos más quisiéramos impedir la insinuación de ese vacío: vacío de espacio, vacío de tiempo. Con el abrazo, lo que se pretende es conjurar la amenaza de ese vacío (22).

La palabra ofrece la posibilidad de disolver ese vacío que deja la ausencia del ser querido cuando éste ha muerto. Como escribió Montaigne (2007), "sólo por la palabra somos hombres y nos mantenemos unidos entre nosotros" (49). Incluso ese lazo persiste después de la muerte, en la evocación escrita. La lectura disipa la lejanía discursivamente, porque entre más tiempo pase entre el momento de la desaparición y el presente, la presencia tiende a diluirse. Con el paso del tiempo, el olvido puede dominar y dejar únicamente el enorme dolor y vacío que queda en los personajes ante la experiencia de la muerte y la ausencia del ser amado. Como bien escribe Bataille (2008), "el vacío no es nada, el olvido no es nada: si los sollozos preceden al vacío, si preceden al olvido, entonces el vacío, el olvido son la ausencia de sollozos" (371). Abad Faciolince decide combatir a través de una innegable fuerza discursiva el vacío y el olvido, cuando sustituye los sollozos por las palabras, y la ausencia, por la existencia literaria. Con una lograda estética, y la magnífica construcción del personaje paterno, consigue trascender la sensación de vacío con las páginas llenas de vida del doctor Abad Gómez.

\section{III}

"La muerte es a la vez la negación pura y simple de la esencia y la negación pura y simple del ser".

Vladimir Jankelévitch.

"No es la muerte la que se lleva a los que amamos. Al contrario, los guarda y los fija en su juventud adorable. No es la muerte la que disuelve el amor, es la vida la que disuelve el amor".

Héctor Abad Faciolince.

Olvido y memoria. Se percibe la realidad con los sentidos antes de racionalizarla. La memoria es la sensación asimilada, y es 
involuntaria, pues nadie se puede sustraer a ella. La acumulación de memorias individuales conforma la colectiva, y por tanto, la historia, que no es sino una suma de verdades, aunque "la verdad suele ser confusa; es la mentira la que tiene siempre los contornos demasiado nítidos" (Abad Faciolince, 2009: 150). Entre la verdad y la mentira: el lector conocerá en las páginas de El olvido que seremos una acumulación de recuerdos: "si la vida es el original, el recuerdo es una copia del original y el apunte una copia del recuerdo" (15). La literatura comparte junto con la historia su relevancia como registro. Para Ricoeur (2000), "la memoria, reducida a la rememoración, opera siguiendo las huellas de la imaginación" (21). Por ello, en la novela hay una simbiosis entre experiencia vital e imaginación, que traslada al lector a un contexto de fragilidad de la vida, precisamente por ese abismo entre lo real y lo ficticio.

Cuando se multiplican las muertes, pareciera abaratarse la vida y se teme al olvido, porque, como escribe Fernando Vallejo (2006), "la fugacidad de la vida humana a mí no me inquieta; me inquieta la fugacidad de la muerte: esta prisa que tienen aquí para olvidar" (40). Cuando las muertes se multiplican, hay un interés más que evidente de las autoridades por enmascararlas, minimizar su valor y tratar de que se olviden, para evadir su responsabilidad en el asunto. Sobre todo porque "los muertos no se mueren cuando los entierran" (Collazos, 2010: 135); siguen viviendo en los deudos. Perviven en su memoria, como escribe Abad Faciolince (2011a), más aún "si recordar es pasar otra vez por el corazón, siempre lo he recordado" (391), y no sólo lo ha recordado, se ha encargado de que muchísimos lectores lo conozcan y lo recuerden, desafiando al olvido: "la memoria es un espejo opaco y vuelto añicos, o, mejor dicho, está hecha de intemporales conchas de recuerdos desperdigados sobre una playa de olvidos" (208).

La obra de Faciolince parece establecer una lucha frontal contra el olvido. El recuerdo es de alguna manera, para el ser humano, un modo de saber quién es él mismo. La memoria individual va conformando la colectiva, y en la novela es muy evidente que la lucha por rememorar al padre también apela al lector a preguntarse qué sucede cuando olvidamos y por qué es necesario recordar. En el tercer soneto de Borges, que titula la novela, se lee:

Ya somos el olvido que seremos

El polvo elemental que nos ignora y que fue el rojo Adán y que es ahora todos los hombres y los que seremos. Ya somos en la tumba las dos fechas 
del principio y el fin, la caja, la obscena corrupción y la mortaja,

los ritos de la muerte y las endechas (364-365).

En la obra el lector observa que el personaje sigue vivo en el recuerdo de los otros personajes, del escritor, e incluso de los asesinos, pues atestigua cuando un sobrino-nieto del doctor Abad observa en un noticiario una nota referente al aniversario luctuoso del tío y escucha a unos paramilitares decir: "a ese hijueputa fue uno de los primeros que matamos en Medellín [...] Era un comunista peligrosísimo; y al hijo hay que ponerle cuidado, porque va por el mismo camino" (324). Tanto el hijo Abad Faciolince, como los amigos y algunos integrantes de la lista, se vieron obligados a salir del país para seguir vivos. Se vieron obligados a autoexiliarse $\mathrm{e}^{12}$.

No se puede ignorar que la manera en que lo percibían los otros, las huellas que iba dejando a través de cada uno de sus artículos, sus protestas, y su firme compromiso con las víctimas, estén vinculados necesariamente con la imagen que se iba construyendo en el imaginario y la memoria de quienes lo veían como enemigo, hasta llegar al límite de mandarlo a asesinar. Escribe Agamben (2011) que Deleuze define "la operación del poder como un separar a los hombres de aquello que pueden, es decir de su potencia (59). Sus asesinos, al estar imposibilitados para callar la potencia de su voz y la trascendencia de su compromiso social, lo silencian definitivamente. Al mismo tiempo, se iban construyendo dos imágenes radicales: una negativa y otra positiva. De ese modo, la bondad del doctor también desencadenará una lucha de fuerzas, cuyo final, a primera vista, pareció favorecer a esa Colombia tan llena de violencia y reaccionaria, pero que con el tiempo, a través de la memoria logró, recuperar los esfuerzos por ayudar al otro.

Los rumores que fueron creciendo gracias a diferentes situaciones generadas por diversos personajes, cuya visión de la vida y percepción de la problemáticas eran distintas, originaron una postura unánime que derivó en un asesinato. Todo esto mediante las palabras que indicaban su nombre en un papel. Y paradójicamente, también a través de ellas, que expresan su nombre en un papel y que lo ubican

\footnotetext{
${ }^{12}$ El autoexilio para sobrevivir fue una realidad constante en Colombia tras la incontable cantidad de episodios violentos que han sucedido, y es una vivencia que empieza a hacerse cada vez más recurrente en México, sobre todo en los casos de los periodistas que viven en constante peligro. Pues hubo un momento en que, como escribe Abad Faciolince: "Las ciudades y los campos de Colombia se cubrían cada vez más con la sangre de la peor de las enfermedades padecidas por el hombre: la violencia." (313).
} 
dentro de una trama y lo delinean como personaje, se recupera la memoria de su existencia, y en ese proceso, mediante la palabra los lectores, le devuelven la vida que le arrebataron. De ese modo podría aseverarse que la memoria de su hacer en el mundo originó su muerte; precisamente la recuperación de ese hacer le da vida nuevamente en los textos que Abad Faciolince le permite habitar.

Afirma Maurice Halbwachs (citado por Burke, 2000) que "los grupos sociales construyen los recuerdos. Son los individuos los que recuerdan en sentido literal, físico, pero son los grupos sociales los que determinan lo que es 'memorable' y cómo será recordado' " (66). Cuando se reflexiona sobre el desolador paisaje humano que invadió a Colombia, presente en distintas fases en otros países, y ahora conocida a través de testimonios directos, en textos testimoniales o en las diversas perspectivas o poéticas a partir de los cuales los periodistas, la historia y la literatura recuperan, interpretan y transmiten esa experiencia que marcó y continúa marcando a toda una generación, entonces es la memoria colectiva, esa suma de identidades construidas, la que en unos años permitirá vislumbrar a la distancia las dimensiones de lo vivido. Y es que, aunque no se llegue a comprender esta época, resulta necesario recordar, y deberán conocerla quienes no la padecieron o no la están viviendo.

Sobre todo, porque "en una partida de ajedrez, como en la vida, no se puede rectificar; pero una vez jugada la partida, se pueden analizar las variantes. La literatura analiza las variantes de la vida" (Abad Faciolince, 2009: 255). A partir de la escritura, Abad Faciolince analiza las variantes con que perdió a su padre y concluye el duelo cuando, en la misma novela, describe ese doloroso proceso.

Guardé en secreto, durante muchos años, esa camisa ensangrentada, con unos grumos que se ennegrecieron y tostaron con el tiempo. No sé por qué la guardaba. Era como si yo la quisiera tener ahí como un aguijón que no me permitiera olvidar cada vez que mi conciencia se adormecía, como un acicate para la memoria, como una promesa de que tenía que vengar su muerte. Al escribir este libro la quemé también, pues entendí que la única venganza, el único recuerdo y también la única posibilidad de olvido y perdón, consistía en contar lo que pasó y nada más (344).

El olvido que seremos disipa el olvido que conlleva la muerte, y es mediante el recuerdo como de alguna manera el ser humano recuerda quién es, aunque el doctor Héctor Abad nunca tuvo temor de que no se supiera quién fue en la tierra. Vivió y murió sin miedo, 
y su valentía está expresada en los versos de Borges que acunaba el personaje en su ropa en el momento de ser asesinado. Está expresada en el título de la novela. Ese miedo quizás sólo reside en quienes se niegan a olvidar, o en quienes temen ser olvidados:

\author{
No soy el insensato que se aferra \\ al mágico sonido de su nombre; \\ pienso con esperanza en aquel hombre \\ que no sabrá quien fui sobre la tierra. \\ Bajo el indiferente azul del cielo, \\ esta meditación es un consuelo (365).
}

Llevar en su camisa esos versos, además de dar pie a que Héctor Abad Faciolince escribiera Traiciones de la memoria, para confirmar la veracidad de la autoría, permite terminar de construir la figura del doctor, con su particular sensibilidad y el amor por la literatura y otras artes. Resulta "hermoso que unas letras manchadas por los últimos hilos de su vida hayan rescatado, sin pretenderlo, para el mundo, un olvidado soneto de Borges sobre el olvido" (2009: 180). De alguna manera, la hibridación genérica conlleva también una necesidad de ofrecer un mayor marco de posibilidades al decodificar la realidad a través de diversos géneros, y por lo tanto, diversos mecanismos textuales en la reconstrucción de la realidad. En este libro híbrido entre relato familiar, autobiografía, apología de la figura paterna, reflexión social sobre los conflictos y la guerra en Colombia, y libro de memorias, que yo he venido llamando novela, cabe recordar que "como decía el mismo Borges, y es un hecho supongo que neurológico de la memoria, se recuerdan las cosas no tal como ocurrieron, sino tal como se relatan en mi último recuerdo, en mi última manera de contarlas. El relato sustituye a la memoria y se convierte en una forma de olvido. Sin embargo, tiene que haber elementos de memoria precisa" (149). Memoria, imaginario y realidad regalan al lector la experiencia de conocer a un hombre extraordinario en medio de la podredumbre de la ambición y de la guerra del narcotráfico, lo cual lo vuelve más extraordinario al subsistir en ese ambiente hostil.

No cabe duda de que "la guerra se ve como algo que entablan los hombres de modo inveterado, sin inmutarse ante la acumulación del sufrimiento inflingido; y la representación de la guerra con palabras o imágenes precisa de un agudo y resuelto desapego" (Sontag, 2010: 67). Sin embargo, en dicho texto la voz narrativa no consigue ese desapego del testigo ajeno a los acontecimientos, pues será juez y parte de ellos. 
Para concluir este artículo, cabe aclarar que resulta muy subjetiva la selección de los datos narrados y los diferentes tonos en que oscila el discurso, porque toda recuperación de la memoria en gestación ya lo es, pues "así es la memoria: lo que uno recuerda, otro lo olvida, lo que es importante para uno, para otro carece de importancia y lo borra para siempre, llegándolo a negar aunque le haya ocurrido" (2009: 66). A la subjetividad habitual de la memoria se le agrega la subjetividad con que se reconstruye la propia historia al trasladarla al discurso. Finalmente, como escribe Abad Faciolince en Traiciones de la memoria, "una memoria solamente es confiable cuando es imperfecta, y que una aproximación a la precaria verdad humana se construye solamente con la suma de recuerdos imprecisos, unidos a la resta de los distintos olvidos" (130).

Olvido y memoria, presencia y ausencia fungen como esqueletos para sostener la estructura de la narración, y por ello acudo a Ricoeur (2000), en La memoria, la historia, el olvido, cuando cita a San Agustín, quien creía que "aquello de lo que no nos acordamos, lo retenemos por la memoria; y si no nos acordásemos del olvido, no podríamos en absoluto, al oír ese nombre, reconocer la realidad que él significa; luego es la memoria la que retiene el olvido" (132). Esta reflexión sintetiza el germen de la trama. La esencia humana y la de los personajes se conforma a partir de una suma de olvidos y memoria que los sostiene en su presente, los proyecta hacia el pasado a través de esos vínculos con la conciencia de lo vivido, y necesariamente delinean quiénes serán en su futuro.

Por ello, la palabra y la memoria son determinantes tanto en la trama, como extratextualmente, en el proceso de duelo del escritor: "el trabajo de duelo es el costo del trabajo del recuerdo; pero el trabajo del recuerdo es el beneficio del trabajo del duelo" (100). El duelo de Abad Faciolince alude a un duelo colectivo que está vinculado con las víctimas, sus familiares, sus amigos. Las víctimas de la guerra de las drogas, en el pasado en Colombia y actualmente en México, han pasado de poblar los países latinoamericanos a engrosar los títulos literarios que dan cabida a ese conflicto bélico y sus consecuencias ${ }^{13}$. La palabra del doctor Abad en su vida diaria, en sus artículos periodísticos en los diálogos con su hijo y con los demás personajes, incluso las palabras que lo colocan en una lista de víctimas, se suceden de manera paralela con los recuerdos. Porque la memoria

\footnotetext{
${ }^{13}$ En esa guerra del narcotráfico "cayó Héctor Abad Gómez, víctima de la peor epidemia, de la peste más aniquiladora que puede padecer una nación: el conflicto armado entre distintos grupos políticos, la delincuencia desquiciada, las explosiones terroristas, los ajustes de cuentas entre mafiosos y narcotraficantes." (313).
} 
es una constante dentro de la historia y es determinante para la toma de decisiones de los personajes y para desencadenar acciones posteriores. De acuerdo con Ricoeur, la "memoria herida se ve obligada a confrontarse siempre con pérdidas" (109) ${ }^{14}$. Y cada vez es más larga la lista de víctimas y de deudos: "el recuerdo no se refiere sólo al tiempo: exige también tiempo, un tiempo de duelo" (102). Y ese tiempo se vuelve ahora presente en el territorio mexicano, y se prolonga y se multiplica, y no parece haber manera de detenerlo.

Bataille (2008) escribe que "el 'yo' que muere, que la muerte expulsa, acorralado, se condena a caer en un silencio, en un vacío que no soporta. Aunque cómplice del silencio, cómplice del vacío, está en poder de un mundo donde no hay nada que no se extravíe" (371). En ese extravío de la muerte, donde hubo silencio, hay una potente voz capaz de romperlo, y el vacío se disipa con la presencia de ese personaje, al menos mientras dura la lectura. Porque escribir esta novela puede verse de alguna manera como una despedida, y "escribir la despedida significa, de vez en cuando, ofrecer una palabra a la lejanía que está por llegar, un pensamiento legible, evidente, al vacío que abre en la distancia" (Prete, 2010: 33). La palabra puede significar dos abstracciones tan opuestas: lejanía y cercanía. Se aleja la figura del padre si se ve como despedida y se aproxima a través de la evocación discursiva. El autor rompe todos los límites que lo separan discursivamente. Mediante su imaginario y su palabra se comunica con el padre ausente. Héctor Abad no deja de abrazar al doctor Abad en los diversos textos en que le da presencia.

\section{Bibliografía}

Abad Faciolince, H. (2011a). El olvido que seremos. Barcelona: Lectura. . (2011b). "Álbum". En El amanecer de un marido. Barcelona: Seix Barral.

(2011c). “Manicomio" y "Memento". En Testamento involuntario. Bogotá: Alfaguara. . (2009). Traiciones de la memoria. Bogotá: Alfaguara.

Agamben, G. (2011). Desnudez. Barcelona: Anagrama.

Bataille, G. (2008). La felicidad, el erotismo y la literatura. Argentina: Adriana Hidalgo.

Burke, P. (2000). Formas de historia cultural. Madrid: Alianza.

Collazos, O. (2010). Señor Sombra. Bogotá: La otra orilla.

\footnotetext{
${ }^{14}$ Y más aún cuando se trata de "heridas de memoria colectiva [...] las pérdidas que afectan también al poder, al territorio, a las poblaciones que constituyen la sustancia de un estado" (Ricoeur, 2000: 107, 108). Y en la guerra de las drogas, las pérdidas, afectan todos los niveles de la sociedad.
} 
Teresa García Díaz

Montaigne, M. (2007). Los ensayos. Barcelona: Acantilado.

Ovejero, J. (2012). La ética de la crueldad. Barcelona: Anagrama.

Prete, A. (2010). Tratado de la lejanía. Valencia: Pretextos.

Ricoeur, P. (2000). La memoria, la historia, el olvido. México: F.C.E.

Sontag, S. (2010). Ante el dolor de los demás. Barcelona: Mondadori.

Vallejo, F. (2006). La virgen de los sicarios. Madrid: Alfaguara, 2006. 
